\title{
Deterioration of Ground Water Quality in Eloor -Edayar Industrial Belt
}

\author{
Ambily A.P, Jailakshmi Menon
}

\begin{abstract}
Ground water contamination has become a serious problem due to rapid growth of population, industrialization and high rate of Urbanization. Untreated or partially treated industrial effluents discharged in to water bodies or ponds and sludge heaps causes severe ground water pollution in industrial belts. In the present investigation an attempt has been made to study the extent of ground water pollution in an area of $500 \mathrm{~m}$ around the Eloor-Edayar Industrial belt. Results revealed that the ground water near to the Industrial zone is already polluted and possible remedial measures are suggested.
\end{abstract}

Index Terms: Pollution, Ground water, Eloor, river Periyar.

\section{INTRODUCTION}

India is the largest consumer of groundwater in the world, with an estimate of around 230 cubic kilometers per year, more than a quarter of the global total [7]. As its rate of extraction has remained high, groundwater replenishment has been unable to sustain water levels in many of the country's aquifers. Inadequate rainfall, exceptionally high water demand owing to rise in population, urbanisation and rapid industrialization are the major reasons for the decline in ground water. Groundwater depletion has very severe consequences on India's water security, food security, health and the livelihoods of its population. Groundwater resources in India are further deteriorating due to high levels of contamination from rapid industrial growth, fast urbanization and other man made activities. Contamination and over-extraction are compounding problems. It is currently a race against rising population and managing water resources and the key is to conserve fresh water resources

Eloor, located in Ernakulam district of South India is the largest industrial belt in Kerala with more than 247 chemical industries. It is located on the banks of river Periyar [1].These industries have been largely responsible for degradation of both ground water and water in river Periyar. This can be attributed to the non scientific way of industrial effluent disposal. The situation is so alarming that now this industrial belt is known as "toxic hot spot" in Kerala.

In the initial phase of industrialisation, people of Eloor whole heartedly welcomed the Industries and Eloor witnessed rapid socio-economic growth. Later on these Industries posed a threat to the nature and environment by

Revised Version Manuscript Received on 10 September, 2019.

Dr. Ambily A.P, Associate Prof., Dept. of Civil Engineering, Saveetha Engineering College, Chennai, Tamil Nadu, India

Dr. Jailakshmi Menon, Associate Professor, Dept. of Civil Engineering, Saveetha Engineering College, Chennai, Tamil Nadu, India degrading the quality of water and air in the surrounding areas. Deterioration of water quality changed people's perception on industrialization in the early 1980's. This forced many of the industries to close down creating a dent in the progress of development. An attempt is made to study the extent of ground water pollution in an area of $500 \mathrm{~m}$ around the Industrial Zone and possible remedial measures are suggested.

\section{STUDY AREA}

Eloor, industrial hub of Kerala, is an island spread over an area of $14.21 \mathrm{~km} 2$ [1], located in Ernakulam district, between north latitudes $9^{\circ} 3^{\prime}$ and $10^{\circ} 6^{\prime}$ and east longitudes $76^{\circ} 20^{\prime}$ and $76^{\circ} 28^{\prime}$ [2]. Eloor-Edayar industrial belt is situated on the banks of river Periyar with a population of more than 40,000 Fig.1 shows the index map of Eloor Edayar Industrial belt. Study was conducted in an area which falls within $500 \mathrm{~m}$ towards North of the industrial zone at Eloor-Edayar industrial belt.

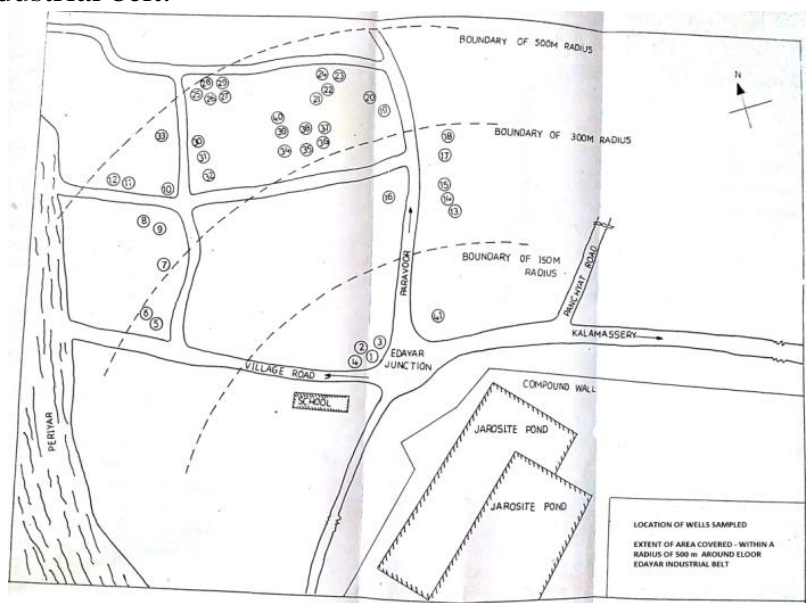

Fig 1 : Index map of Eloor Edayar Industrial belt

River Periyar is the longest river in Kerala, travelling 244 $\mathrm{km}$ within the state. It originates from Sivagiri group of the hills situated at Sundaramalai in the Western Ghats at the elevation of $1830 \mathrm{~m}$ above mean sea level (MSL) and flows towards the west. This river is of at most significance in the economy of Kerala as it is the site of largest hydro electric project, Idukki, in the state and it flows along a region of industrial and commercial activity. It is one of the few perennial rivers in the region and provides drinking water for several major towns. Periyar river is located to the west of the study area. 
The industries located on the banks of river Periyar include chemical industries, manufacturing petrochemical products, rare-earth elements, pesticides, fertilizers, rubber processing chemicals, zinc and chrome products, leather products, etc., These industries depend on the river for intake of process water and disposal of effluents. More than $17.35 \mathrm{ml}$ of highly polluted effluents per day are discharged into the river Periyar or stored in Jarosite ponds or sludge heaps within the industrial premises. These effluents include DDT, Endosulfan, heavy metals like manganese, zinc, cadmium and mercury, water nutrients like nitrates, phosphates and sulphates and over a hundred other organic compounds which made Eloor the 35th most toxic hotspot in the world [3].

\section{METHODOLOGY}

Present study was performed as an attempt to draw attention to the overlooked problem of well water quality by presenting much needed data which can also form the basis for further detailed investigation

A preliminary study was conducted by collecting water samples from 41 wells. Five wells were located within $150 \mathrm{~m}$ radius of the industrial units. Eight wells were falling within a distance of 150 to $300 \mathrm{~m}$ and the remaining 28 wells were between 300 to $500 \mathrm{~m}$ from the industrial unit. Location of wells are indicated in Fig.1. Samples were collected during dry and wet season. Dry season is the period from January to June and wet season is from July to December. Representative samples from each of the wells were collected in sterile glass bottles. The sample containers were thoroughly washed and rinsed with $1+1$ nitric acid and then with distilled water before taking samples. The samples were tested for the presence of Zinc and Sulphate and $\mathrm{pH}$ values were also measured.

A questionnaire was also circulated among the residents of the colony so as to obtain a general awareness of the problem faced by the residents. The questionnaire were open ended and was pertaining to the quality of well water in their houses. Questions were also raised regarding the suitability of water for drinking and other uses. The collected data were analysed and the results are given in the following section.

\section{RESULTS AND DISCUSSION}

The test results on water samples for the presence of zinc, sulphate and $\mathrm{pH}$ are given in Table I to Table III.

\section{A. Wells Located within $150 \mathrm{~m}$}

Five wells were investigated within this zone and the results are indicated in Table I. Out of this well no. 41 is found to be very highly contaminated which is located in the North-East direction of the industrial zone. The $\mathrm{pH}$ of water in dry season is 4.79 and wet season is 5.5 against the permissible $\mathrm{pH}$ of 6.5 to 8.5 as per drinking water standards [6]. In general the soil type of Eloor is sandy loam of alkaline nature with higher $\mathrm{pH}$ value [2]. The lower $\mathrm{pH}$ of ground water indicates acidity due to the presence of industrial pollutants.

The concentration of zinc in well no. 41 is $180 \mathrm{mg} / \mathrm{l}$ in dry season and $20 \mathrm{mg} / \mathrm{l}$ in wet season against the permissible limit of $5 \mathrm{mg} / \mathrm{l}$ as per drinking water standards. In dry season the concentration of sulphate is $50 \mathrm{mg} / \mathrm{l}$ more and in wet season it is $10 \mathrm{mg} / \mathrm{l}$ less than the permissible standard. The results indicate that the effluents stored in the dumping yards/ponds entered in to the ground water table through infiltration along with rain water. The quality of water in well no. 41 is an indication that the transport of pollutants along with underground water is predominantly towards the north east direction.

\section{B. Wells Located within $150 \mathrm{~m}$ to $300 \mathrm{~m}$}

Eight wells were investigated within this zone. The results are summarized in Table II. Well nos. 5, 6, 15 and 16 were not showing the presence of pollutants, where as in the other wells the water is slightly acidic and traces of sulphate is present. The situation will get aggravated, if the transport of pollutants as identified in the north-east direction within 150 $\mathrm{m}$ zone is not properly controlled.

\section{Wells Located within $300 \mathrm{~m}$ to $500 \mathrm{~m}$}

Twenty eight wells were investigated in this zone and the results are indicated in Table III. Most of the wells were showing permissible limits of $\mathrm{pH}$ with traces of sulphate. In Kerala, generally, the ground water shows a $\mathrm{pH}$ of 6 to 8 , sulphate of Zero to $3 \mathrm{mg} / \mathrm{litre}$ and Zinc will be almost zero in unpolluted area. Well no.33 located in the north west direction and closer to the Periyar river showed a $\mathrm{pH}$ of 5.0 and 5.2 indicating water as slightly acidic. Presence of sulphate of the order of $60 \mathrm{mg} / \mathrm{l}$ in dry season and $40 \mathrm{mg} / \mathrm{l}$ in wet season is seen. The lower $\mathrm{pH}$ and presence of sulphate may be attributed to the infiltration of the polluted water from Periyar river.

The results clearly indicate the presence of sulphate and zinc beyond the permissible limits of drinking water standards in the well within $150 \mathrm{~m}$ around the industrial zone in the north-east direction. This reveals that the effluents stored in the jarosite ponds within the industry premises or sludge stored in the form of heaps forms leachate due to mixing with rain water which percolates and reaches the ground water.

It can be seen from Table III that even though well nos 7, 8, 9, 10, 11 and 12 are closer to the industrial unit than well no. 33 , the former does not show the presence of excess sulphate. Well no. 33 which is located near to the Periyar river showed presence of sulphate greater than the permissible limits. This points to the fact that the ground water near the Periyar river is also polluted due to the infiltration of water from river. This can be further attributed to the disposal of effluents from the industrial units to the Periyar river,

The results after circulating the questionnaire inferred that in majority of the wells, the water is not suitable for drinking, cooking etc., Around 50\% of the residents resorted to treatment options like addition of lime and potassium permanganate to the well water. 
People were of the opinion that proper remedial measures should be taken to avoid water contamination in the area of study.

Table I Test Results on water samples for wells located within $150 \mathrm{~m}$

\begin{tabular}{|c|c|c|c|c|c|c|c|}
\hline \multirow[t]{3}{*}{$\begin{array}{l}\text { Well } \\
\text { No. }\end{array}$} & \multirow{3}{*}{$\begin{array}{l}\text { Locatio } \\
\mathrm{n} \text { of the } \\
\text { well } *\end{array}$} & \multicolumn{2}{|c|}{$\mathrm{pH}$} & \multicolumn{2}{|c|}{$\begin{array}{c}\text { Zinc } \\
(\mathrm{mg} / \mathrm{l})\end{array}$} & \multicolumn{2}{|c|}{$\begin{array}{c}\text { Sulphate } \\
(\mathrm{mg} / \mathrm{l})\end{array}$} \\
\hline & & \multicolumn{2}{|c|}{ Season } & \multicolumn{2}{|c|}{ Season } & \multicolumn{2}{|c|}{ Season } \\
\hline & & Dry & Wet & Dry & Wet & Dry & Wet \\
\hline 1 & NW & 6.46 & 6.52 & 0 & 0 & 2 & 2 \\
\hline 2 & NW & 6.47 & 6.56 & 0 & 0 & 2 & 2 \\
\hline 3 & NW & 6.43 & 6.51 & 0 & 0 & 3 & 3.5 \\
\hline 4 & NW & 5.43 & 6.1 & 2 & 1 & 25 & 60 \\
\hline 41 & $\mathrm{NE}$ & 4.79 & 5.5 & 180 & 20 & 240 & 270 \\
\hline
\end{tabular}

* Location of the well indicated is with respect to the industrial unit

** NW - North West, NE - North East

Table II Test Results on water samples for wells located within $150 \mathrm{~m}$ to $300 \mathrm{~m}$

\begin{tabular}{|l|l|l|l|l|l|l|l|}
\hline \multirow{2}{*}{$\begin{array}{l}\text { Well } \\
\text { No. }\end{array}$} & $\begin{array}{l}\text { Locati } \\
\text { on of } \\
\text { the }\end{array}$ & \multicolumn{2}{|c|}{$\mathrm{pH}$} & \multicolumn{2}{c|}{ Zinc (mg/l) } & \multicolumn{2}{c|}{$\begin{array}{c}\text { Sulphate } \\
(\mathrm{mg} / \mathrm{l})\end{array}$} \\
\cline { 3 - 8 } & well $*$ & \multicolumn{2}{|c|}{ Season } & \multicolumn{2}{c|}{ Season } & \multicolumn{2}{c|}{ Season } \\
\cline { 3 - 8 } & Dry & Wet & Dry & Wet & Dry & Wet \\
\hline 5 & NW & 6.1 & 6.2 & 0 & 0 & 12 & 2 \\
\hline 6 & NW & 6.2 & 6.1 & 0 & 0 & 12 & 2 \\
\hline 13 & NE & 5.09 & 5.5 & 0.1 & 0 & 30 & 4 \\
\hline 14 & NE & 5.0 & 6 & 0.1 & 0 & 25 & 3 \\
\hline 15 & NE & 6.0 & 6.2 & 0 & 0 & 2 & 1 \\
\hline 16 & NE & 6.74 & 6.8 & 0 & 0 & 1 & 1 \\
\hline 17 & NE & 5.09 & 5.3 & 0 & 0 & 10 & 3 \\
\hline 18 & NE & 5.23 & 5.3 & 0 & 0 & 10 & 2 \\
\hline
\end{tabular}

Table III Test Results on water samples for wells located within $300 \mathrm{~m}$ to $500 \mathrm{~m}$

\begin{tabular}{|c|c|c|c|c|c|c|c|}
\hline \multirow[t]{3}{*}{$\begin{array}{l}\text { Well } \\
\text { No. }\end{array}$} & \multirow{3}{*}{$\begin{array}{l}\text { Locatio } \\
\mathrm{n} \text { of the } \\
\text { well * }\end{array}$} & \multicolumn{2}{|c|}{$\mathrm{pH}$} & \multicolumn{2}{|c|}{ Zinc (mg/l) } & \multicolumn{2}{|c|}{$\begin{array}{c}\text { Sulphate } \\
(\mathrm{mg} / \mathrm{l})\end{array}$} \\
\hline & & \multicolumn{2}{|c|}{ Season } & \multicolumn{2}{|c|}{ Season } & \multicolumn{2}{|c|}{ Season } \\
\hline & & Dry & Wet & Dry & Wet & Dry & Wet \\
\hline $\begin{array}{l}7, \quad 8, \\
9,10, \\
11, \\
12\end{array}$ & $\mathrm{NW}$ & $\begin{array}{l}6.0 \\
\text { to } \\
6.2\end{array}$ & $\begin{array}{l}6.1 \\
\text { to } \\
6.4\end{array}$ & 0 & 0 & 12 & 2 \\
\hline 33 & $\begin{array}{l}\text { NW } \\
\text { (Close to } \\
\text { Periyar } \\
\text { river) }\end{array}$ & 5.0 & 5.2 & 0 & 0 & $\begin{array}{l}36 \\
0\end{array}$ & 240 \\
\hline $\begin{array}{l}19 \text { to } \\
32, \\
34 \text { to } \\
40\end{array}$ & N-NE & $\begin{array}{l}6.1 \\
\text { to } \\
6.3\end{array}$ & $\begin{array}{l}6.2 \\
\text { to } \\
6.7\end{array}$ & 0 & 0 & 2 & 1 \\
\hline
\end{tabular}

The study reveals that the ground water pollution has serious impacts on health and environment of the community in Eloor- Edayar industrial belt. The wastes stored in ponds or heaps often enters the surface water as run-off during the monsoons or mixes with percolating rain water and reaches the ground water table disturbing its quality at great concern

Due to the discharge of untreated or partially treated effluents over several decades, the water in Periyar is flowing sluggishly, with deep black, red or yellow colour. Fig. 2 depicts the view of Periyar river polluted by industrial effluents.

Presence of these pollutants in surface and ground water resulted not only in higher incidences of ailments like bronchitis, asthma, skin diseases and even cancer for users but also an increase in a wide set of systemic disorders [5]. The children in the locality are facing higher chances of malformation due to congenital and chromosomal aberrations caused by the pollution.

The levels of contamination in the area have disastrous effect on the ecosystem also. Everything from vegetables to eggs to cow's milk shows alarming presence of contamination by various chemicals. Multiple studies have shown that the discharge of effluents has been catastrophic for the aquatic life of the region. Massive Fish kills of smaller and larger fishes are a common seen in the polluted stretches of the river. Fig. 3 shows the view of massive fish kills in Periyar river. Degradation of the river is also visible in the form of falling stock of fish [5]. While there were 35 species of fish in the periyar in 1980 [4], the number had been fallen to just 12 at present [8].

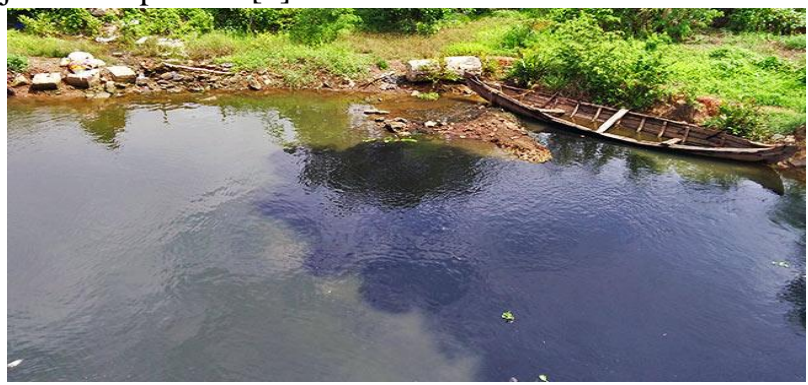

Fig. 2 (a): View of Periyar river polluted by Industrial

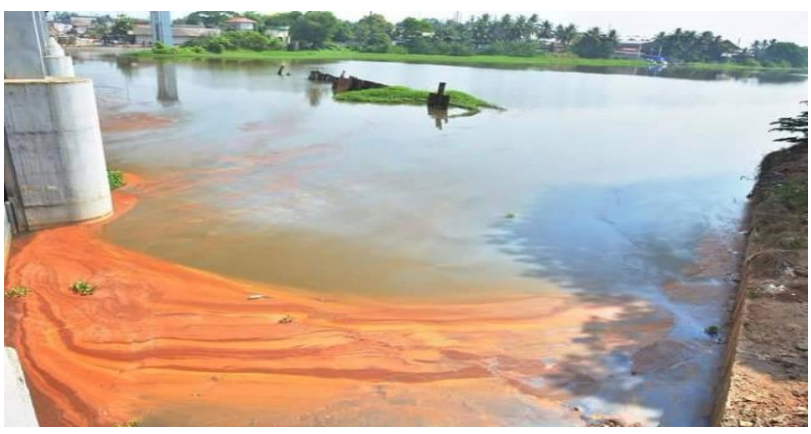

Fig. 2 (b): View of Periyar river polluted by Industrial 


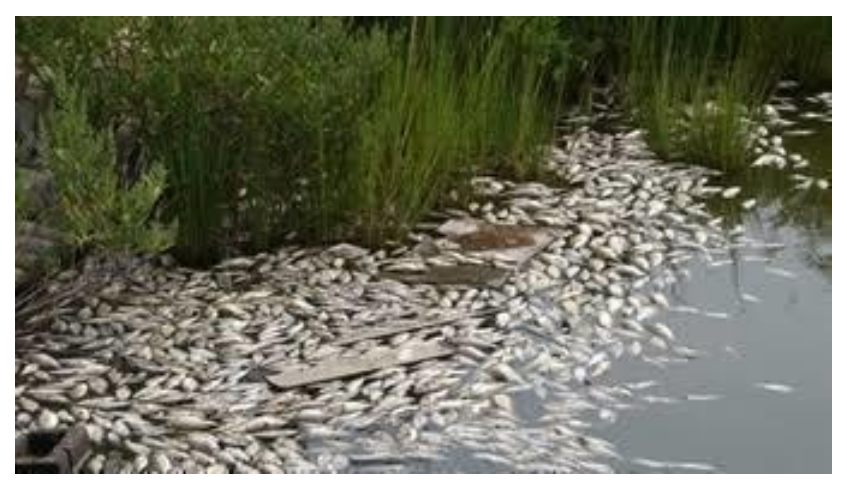

Fig. 3: View of massive Fish kills in Periyar River

\section{RECOMMENDATIONS}

1. Groundwater quality monitoring network stations should be established

2. The ponds within the industrial premises shall be protected by effective liners to ensure zero discharge

3. The effluents discharged to Periyar shall be treated to remove the pollutants. Dedicated treatment plants shall be installed for each industry

4. Developing an eco-friendly green zone surrounding the industrial belt should be made mandatory.

\section{CONCLUSION}

The results clearly reveal that the ground water near to the industrial unit is already polluted and there is transport of pollutants along with underground water predominantly towards the north east direction .

It is essential to initiate measures to check the pollution from industrial effluents through strict enforcement of legislation for industries

Possible recommendations based on the study are highlighted.

\section{REFERENCES}

1. K. Sainul Abidin, R. Ganapathi Raman, R. Selvaraju, R, Valliappan. "Pollution Study on Periyar river water and sediment samples at Eloor panchayat," Indian journal of Environment and Ecoplan. vol. 16 (1), 2009, pp. 193-198.

2. D. R. Thomas, B. Sunil, C. Latha, " Physico Chemical analysis of well water at Eloor district area-seasonal study," Current world Environment. vol. 6(2), 2011, pp. 259-264.

3. P. Nimisha, S. Sheeba, "Detection of heavy metal concentration of water in lower reaches of the Periyar river, Kerala," Journal of aquatic biology and fisheries, vol. 2, 2004, pp. 403-409.

4. T. V Ramachandra, M. D Subash Chandran, N. V. Joshi Sumesh Dubani. "Exploiting Biodiversity and Ecology of General Westen Ghats," ENVIS Technical Report:39, March 2012.

5. T. O. Alphons Logoir. "Historical study on impact of industrialization in Ernakulam District with special reference to Eloor," The Executive summary of minor project. MRP(H)-1405/10-11/KLMG 017/UGC-SWRO, December 2010. http://www.shcollege.ac.in/Images/Media/Dr.\%20T.O.\%20Alpho ns\%20Ligoir.pdf

6. IS: 10500:2012 Drinking water specifications, Second revision, Bureau of Indian Standards. India.

7. Deep Wells and Prudence: Towards Pragamatic Action for Addressing Ground Water Over Exploitation in India. World Bank. 2010. Washington. DC: 20433.

https://siteresources.worldbank.org/INDIAEXTN/Resources/2955 83-1268190137195/DeepWellsGroundWaterMarch2010.pdf

8. The Periyar is dying: How south Kerala's lifeline has become an industrial sewage drain. The News Minute, 14th July 2017.

https://www.thenewsminute.com/article/periyar-dying-how-south-

\section{AUTHORS PROFILE}

Dr. Ambily A.P. Associate Prof. Dept. of Civil Engineering Saveetha Engineering College Thandalam, Chennai ambily@saveetha.ac.in Research Work: Experimental and Numerical Evaluation of Stone Columns in Soft Clay No. of International Journal Publication: 1 No. of Conf Publications: 5 Membership: Member IGS, Chennai chapter

Dr. Jailakshmi Menon, Associate Professor, Dept. of civil Engineering,, Saveetha Engineering College, Chennai, jailakshmimenon@saveetha.ac.in Research Area: Modeling and Control of Irrigation Canals No. of Publications :2No. of Conference Publications: 4 